\title{
La historiografía de la Revuelta Agermanada: el lugar ausente del relato histórico
}

\author{
The historiography of the agermanada revolt: the absent place of the historical narrative
}

Fecha de recepción: septiembre de 2018. Fecha de aceptación: noviembre de 2018.

\begin{abstract}
Resumen
Al amparo de la primera crisis del sistema feudal y en el contexto del ciclo de luchas sociales y políticas a las que dio lugar, cobró cuerpo la revuelta agermanada (1519-1522). La historiografía valenciana convirtió a esta revuelta en objeto de estudio privilegiado con renovadas contribuciones de interés, porque que el acontecimiento evoca y rediscute la identidad y la autonomía local. Pero no todos los aspectos que involucra el análisis del conflicto han merecido la misma atención por parte de los historiadores, ni la misma valoración obtuvieron de ellos las dos etapas de la lucha social. El presente artículo intenta un relevamiento de la historiografía especializada en torno al caso, a fin de poder establecer un balance de estas formas de interpretación, en cuanto a la comprensión de la segunda y decisiva fase de la revuelta, cuya importancia postulamos para la comprensión del conjunto del proceso histórico.
\end{abstract}

\footnotetext{
Abstract

Under the first crisis of the feudal system and in the context of the cycle of social and political struggles to which it gave rise, the revolt agermanada (1519-1522) took shape. The Valencian historiography turned this revolt into an privileged object of study with renewed contributions of interest, because the event evokes and rediscovers the local identity and autonomy. But not all the aspects that involve the analysis of the conflict have deserved the same attention on the part of the historians, nor have the two stages of the social struggle obtained from then the same evaluation. The present article tries a survey of the specialized historiography around the case, in order to be able to establish a balance of these forms of interpretation, as for the understanding of the second and decisive phase of the revolt, whose importance we postulate for the understanding of the set of the historical process.
}

\section{Palabras clave}

Historiografía conflictos sociales revuelta agermanada radicalización

\section{Keywords}

Historiography social conflicts agermanada revolt radicalization 
1. Una síntesis de la revuelta en: Vallés Borràs (2000: 11-20).

Una síntesis de la his toriografía especializada en: Durán (1975: 25-62).
3. Las mismas fases en líneas generales describió históricamente la historiografía española: Barros (1997: 191-214).
$\mathrm{Al}$ amparo de la primera crisis del sistema feudal y en el contexto del ciclo de luchas sociales y políticas a las que dio lugar, cobró cuerpo la revuelta agermanada (1519-1522) que tuvo por epicentro el Reino de Valencia y extendió sus influencias por el Reino de Mallorca, por toda la región catalano-aragonesa y sobre los levantamientos antiseñoriales comuneros fronterizos. En los inicios del reinado de Carlos V se construyó un gobierno local rebelde que abrió un compás de reformas en sentido progresivo y permitió una ampliación de la participación política. El conflicto había enfrentado a los sectores del privilegio (señores jurisdiccionales, alto clero y oligarquía ciudadana, secundados por vasallos moriscos y esclavos) con los no privilegiados (gremios, labradores, sectores medios y bajo clero). La profundización de este antagonismo delimitó retrospectivamente dos fases bien marcadas en la comprensión de la revuelta: el tiempo de las reformas de impronta moderada y la fase radicalizada que lleva la impronta de la violencia hasta la derrota final y el castigo punitivo al que dio lugar. ${ }^{1}$ Más allá del sitial de olvido al que la confirió esta derrota, con la emergencia de la historia con status científico, la Germanía se constituyó en objeto de estudio en permanente discusión y actualización en la historiografía valenciana, dado que el acontecimiento rediscute la autonomía e historia local. Pero no todos los aspectos que involucra el análisis del conflicto han merecido la misma atención por parte de los historiadores, ni la misma valoración obtuvieron de ellos las dos etapas de la lucha social. El presente artículo intenta un relevamiento de la historiografía especializada en torno al caso, a fin de poder establecer un balance de estas formas de interpretación, en cuanto a la comprensión de la segunda y decisiva fase de la revuelta, cuya importancia postulamos para la comprensión del conjunto del proceso histórico.

\section{Algunas aclaraciones metodológicas y temáticas previas}

La revisión historiográfica que se presenta sigue el orden cronológico de aparición de los diferentes aportes, señalando las líneas de estudio que se han desprendido históricamente en la indagación de la revuelta e identificando las ideas que contribuyeron en mayor o menor medida a la identificación de los nudos problemáticos del conflicto. La revisión parte de los aportes del siglo XIX ya que hasta entonces el fenómeno había sido condenado al olvido y no habían aparecido contribuciones de interés a su exégesis. Durante siglos, la investigación del caso se caracterizó por su inmersión en el entramado ideológico español y la subordinación conceptual al fenómeno de las Comunidades de Castilla (García Cárcel, 2013: 15-41). La Germanía de Valencia y Mallorca fue relatada muy sucintamente, englobada en el fenómeno comunero castellano y junto a la historia de las conquistas americanas, limitándose a reproducir la voz de los cronistas y su condena moral. ${ }^{2}$ A partir del siglo XIX, la historia de los agermanados servirá para justificar distintos fenómenos políticos e ideológicos románticos, liberales y constitucionalistas y asimismo engendrará una firme condena por parte de las fuerzas reaccionarias. En el siglo XX y durante el breve tiempo de la primavera republicana, reconocerá nuevas instrumentalizaciones, cuando su nombre nominó las avenidas y las plazas del Levante español, recuperando el sentimiento romántico del siglo XIX que convirtiera la revuelta histórica en mito nacional y bandera heroica. Pronto el franquismo devolvió la lucha agermanada al sitial de la Historia al que le habían reservado desde su origen las clases rectoras del orden social. Habrá que esperar a los años '70 para que se redescubran en investigaciones científicas a los agermanados y desde entonces la exégesis del conflicto alumbrará las principales tesis sobre el caso. El mismo se transformó en terreno de estudio abonado hasta el presente con una producción continua a escala local. ${ }^{3}$ Estas serán, por tanto, las distintas escalas que reconoce el bosquejo historiográfico, general y no exhaustivo, sino a través de los principales aportes, que desarrollaremos a continuación. Previo al mismo corresponde establecer dos aclaraciones. 
Prescindimos en este artículo de mencionar los trabajos relativos al movimiento comunero sin dejar de reconocer, no sólo que la indagación histórica sobre la Germanía estuvo íntimamente asociada con el estudio del caso castellano sino que también es sumamente necesario tal consideración conjunta para la comprensión de la conflictividad hispánica del período en términos generales. La investigación sobre estas revueltas describió similares trayectorias en su itinerario: reconoce un primer período de mitificación romántica en el siglo XIX, un segundo momento de retracción cientificista y reaccionario, una recuperación republicana seguido de condena franquista en el siglo XX, hasta el giro producido por la historia con carácter científico en el mismo siglo que favoreció la exégesis de ambos episodios rebeldes. De tal forma, Modesto Lafuente exaltó a los líderes castellanos como símbolos en la lucha contra el despotismo, mientras Marañon los consideró fuerzas retrógradas que se alzaron contra las europeístas liberadoras del emperador (Lafuente, 1853, Parte III, Tomo XI, Cap. VIII; Marañón, 1957). Más allá del esfuerzo pionero de Manuel Azaña (1930), la rehabilitación de la revuelta frente a la visión tradicional, se produce recién en la década de los '70, gracias a los aportes de Maravall, Pérez y Gutiérrez Nieto, quienes producen una revisión radical de la interpretación de las Comunidades. El último de estos autores profundiza el estudio del movimiento en cuanto la lucha antiseñorial (Gutiérrez Nieto, 1973); Joseph Pérez conceptualiza como revolución moderna al conflicto y lo fundamenta en un acabado análisis estructural y sociológico (Pérez, 1978); Maravall sostuvo que las reivindicaciones de la revuelta anticiparon principios del moderno derecho constitucional inglés (Maravall, 1979). A estos aportes, debemos sumar las interpretaciones de Haliczer, Sánchez León, Martínez Gil y José Jerez entre otros, ${ }^{4}$ como prueba de la vigencia y trascendencia de esta temática que dio paso también a importantes obras colectivas como Castilla en llamas o En torno a las Comunidades, libro que reúne los aportes al Congreso Internacional dedicado a la temática comunera (Martínez Gil, 2002; Gómez Vozmediano, 2008). Mencionamos estos aportes de la historiografía sobre el episodio castellano, porque en adelante nos centraremos en los estudios sobre la Germanía, aunque los mismos resultan también una contribución de sumo interés a fin de establecer la singularidad del caso valenciano.

La última aclaración, ya en el campo historiográfico sobre el caso agermanado, es que sólo rescatamos en este artículo aquellos aportes que hicieron de la Germanía objeto de estudio central y no aquellas producciones que sólo refieren a la revuelta tangencialmente. Entre estos últimos no podemos dejar de mencionar los casos de Halperín Donghi y de Américo Castro. Ambos autores, en el contexto de la problemática de su caracterización y con distintos enfoques y objetos de estudio, tienden a entender al movimiento agermanado como fenómeno tradicional. Estas producciones que ubicamos en las décadas de los cincuenta y de los sesenta aluden a la revuelta para poder dar cuenta de distintos fenómenos históricos: el atraso español en el caso de Américo Castro y la expulsión de los moriscos en 1609 en el caso de Halperín Donghi (Castro, 1949; Halperín Donghi, 1955). De igual modo, debemos mencionar que también se han referido al conflicto en forma secundaria, autores que intentaron la conceptualización de conjunto del período de los Austrias y que en general coinciden en la interpretación del caso agermanado como movimiento tradicionalista, en tanto habría tenido por objeto el restablecimiento de la monarquía medieval. Nos referimos a los escritos de Chaunu, Lynch y Domínguez Ortiz, que resultan de suma importancia para comprender más el contexto general de los sucesos en un abordaje general acerca del siglo XVI hispánico, que para el análisis específico del conflicto. ${ }^{5}$

Habiendo establecido estas menciones necesarias, que contribuyen y contribuyeron históricamente, en mayor o menor medida a la comprensión del conflicto, desarrollamos a continuación un bosquejo sobre la producción historiográfica que hizo de la revuelta agermanada su objeto específico de investigación.
4. Mencionamos los aportes en orden de aparición: Haliczer (1987), Martínez Gil (1993), Sánchez León (1998), Jerez (2007).

5. En orden de aparición, destacamos de los autores las siguientes obras: Domínguez Ortiz (1973), Chaunu (1976, 2 vols.), Lynch (1982, 2 vols.). 


\section{La historiografía del siglo XIX.}

Constituye la primera escala del recorrido. Tal como lo señala Ricardo García Cárcel, durante este siglo, pueden distinguirse claramente dos corrientes interpretativas. La "romántico-liberal" que mixtifica el acontecimiento, con su carga de liberalismo sentimental, nacionalismo xenófobo y antiaustracismo, representada entre otros por Fernández Herrero, Vicente Boix, Furiò, Torres de Castilla. Corriente de capital importancia porque, por primera vez, aparece la construcción de la figura del héroe nacional, en torno a los agermanados constituyendo la primera valoración positiva del fenómeno histórico. La otra corriente es el "revisionismo cientificista", que manifiesta su admiración por el centralismo y paternalismo de Carlos V y es reaccionario su punto de vista sobre la revuelta, que puede ser identificado en Quadrado y, en especial, en la completa obra de Dánvila y Collado (García Cárcel, 1975: 10).

El contexto de producción de las obras románticas está marcado por la intención de intelectuales liberales, ligados a la Corte de Cádiz, quienes procuran la resistencia a la dominación extranjera en plena etapa napoleónica. Poetas, escritores y hombres de acción elaboran una interpretación nacionalista que convierte a la Germanía en instrumento de un combate ideológico. Es el tiempo de la "mixtificación de Padilla", el líder castellano, cuando se suceden actos de homenaje, obras literarias, poemas y representaciones teatrales dedicadas a los comuneros y se incorporan a esta mitología liberal la figura de los agermanados. Imbuido del espíritu romántico de la época, Boix ha dedicado varias obras a la revuelta convirtiéndose en un referente indudable de la historiografía del siglo. En él aparece una única conclusión del alzamiento: la pérdida de inmensos tesoros en la guerra civil producto de la represión nobiliaria, que dejó como saldo la muerte de catorce mil agermanados (Boix, 1845, Tomo I: 386). El retrato de algunos de los personajes rebeldes adquiere en sus escritos ribetes novelescos como en el caso del Encubierto. Movimiento antiseñorial y libertario, la Germanía aparece como base ideológica para la lucha del siglo diecinueve y la violencia de sus acciones como "muestras de excesos y fanatismos", productos de la época, como manifestaciones de venganza y justicia frente a la violenta desigualdad nobiliaria (Boix, 1852). La caracterización por la pluma de Boix de los "casos extraños de credulidad y calamidades en Valencia", que muestran la carga de religiosidad en la época, junto a sus relatos de violencia de impresionante fuerza descriptiva, permiten un acercamiento a la temática del milenarismo subversivo, aunque con escasas posibilidades de diferenciar lo que es invención del autor, para legitimar su posición en el siglo XIX, de lo que es producto del clima de la época de la Germanía. La misma disyuntiva se nos presenta al leer a Fernández de Herrero. Su obra está destinada más a la exaltación del movimiento constitucionalista del siglo XIX que a indagar aspectos concretos del acontecimiento, conceptuado como momento mítico de la lucha en pro de la libertad tanto como las Comunidades de Castilla. Publica la "Historia de las Germanías de Valencia y breve reseña del levantamiento republicano de 1869" dedicada al "pueblo" en recuerdo de los agermanados, quienes habrían luchado contra "el absolutismo real". La obra fue prologada por el republicano sevillano Roque Barcia (Fernández Herrero, 1870).

6. Por ejemplo en el caso de Sorolla y de Vicent Peris, líderes agermanados. Torres de Castilla (1866).
Más lacrimógeno es el relato que ensaya Torres de Castilla, quien puntualiza con excesivo detalle la represión de los líderes agermanados, describiendo cómo fueron encarcelados y ajusticiados, sufriendo tormentos y penas de descuartizamiento por las tropas del bando real. ${ }^{6}$ Así Carlos V emerge del relato como un "enemigo de la libertad de los pueblos", quien diera un "golpe de gracia a las instituciones liberales de Valencia de la Edad Media, cayendo ésta en el despotismo". Explica la derrota agermanada por el excesivo regionalismo y espíritu provincial de sus líderes. El autor se apoya en los cronistas Escolano y Sandoval, quienes señalaron las arbitrariedades del poder nobiliario anteriores a la revuelta, para apuntar que existían "causas 
suficientes para la rebelión", aunque "desgraciadamente no había hombres superiores ni en la guerra ni en la política por lo que a pesar de su número fueron vencidos y la opresión se hizo más violenta." Los líderes como Joan Llorenç, en contraste con las fuentes, aparecen como "patriotas no ambiciosos". En definitiva, Torres de Castilla lee la revuelta como una "rebelión de los oprimidos contra los opresores, de los artesanos y trabajadores contra los privilegios del feudalismo"; idea que sintetiza la visión de la corriente romántico-liberal (Torres de Castilla, 1866: 832-835 y 840-844).

En contraste con estos argumentos y como reacción contra la interpretación liberal se erige la obra de Dánvila y Collado, quien refuta la idea de que la Germanía fue una consecuencia del quebranto de derechos y libertades políticas de la época (Dánvila y Collado, 1884: 51-53). Describe la evolución de la organización institucional valenciana desde Jaime I y, encaminado a exaltar la labor de la casa de los Austrias, entiende como causa real para el alzamiento, la relajación de costumbres y moral de la época en Valencia que caracteriza como de "hábitos licenciosos y desordenados, odio a los nobles y rebeldía a los poderes". El carácter de la revuelta en este positivista que vuelve a los argumentos de las crónicas de la época, confirma la importancia del conflicto. "En la cuestión de clases se escondía la cuestión social -afirma Dánvila-. Este es el carácter que reviste el hecho histórico: el movimiento se hubiera circunscripto a una lucha entre la nobleza y los populares sin modificarse la organización foral, sin apropiarse de los cargos públicos, suprimir impuestos, ni combatir el sagrado derecho de propiedad. Pero los prodigios, las inundaciones, la peste, la ausencia de autoridad, la juventud del monarca, las costumbres licenciosas, las predicaciones inoportunas, la influencia de extranjeros provocaron lo contrario. Bajo la máscara del celo religioso, el pueblo se alzó contra la justicia, los jurados y la autoridad eclesiástica". De esta forma, tomaba cuerpo una rebelión movida por la idea de venganza y reparto de bienes nobiliarios, donde al ejército real le faltaban los soldados y "jefes dignos" para reprimirla. En la cuestión de los moros, Dánvila puntualiza cómo fueron bautizados a la fuerza por los agermanados y las consecuencias de esta acción. El autor dedica varias páginas de su relato a la reconstrucción del marco internacional; particulariza la complicidad de los franceses en el alzamiento y la participación de protestantes y judíos en él, exaltando el papel de la Inquisición que puso fin a estas influencias (Dánvila y Collado, 1884: 37-43). Una determinación internacional de las acciones sin comprobación histórica hasta el presente.

Así, mientras Boix y Torres de Castilla denostan la acción de los Austrias justificando la revuelta y exaltando los valores liberales de sus líderes, Dánvila y Collado apela a la fuerza del documento como valor de realidad para continuar la visión negativa de las crónicas de los siglos XVI y XVII. Esta contraposición también es aplicable al caso mallorquino. Antoni Furiò caracteriza a estos líderes como "mártires de las libertades patrias" (Furió, 1841). La "Memoria" de este autor pretende resumir la revuelta mallorquina en base a los Anales de Mut y Sayas y la califica como "glorioso" levantamiento, "contra la prepotencia tiránica de un príncipe que desentendiéndose de los derechos que constituyen la monarquía, quiso unir a la coyuntura de la esclavitud la nación magnánima a que nuestra dicha pertenece". Eleva al rango de héroe al líder agermanado mallorquino: "Colom y sus ilustres compañeros supieron imitar el ejemplo heroico que les trazaron desde el cadalso los adalides de las libertades castellanas en los campos de Villalar". José María Quadrado, en una interpretación opuesta y con las mismas armas que Dánvila, los describe como "desalmados que con sus desafueros cavaron su propia fosa" (Quadrado, 1930: 1-82). Contrario a todos los homenajes dispensados al dirigente agermanado Joanot Colom, lo califica de "gran criminal", sin ideas religiosas ni políticas; mero protagonista de desórdenes, crímenes y saqueos que fueron los únicos medios que empleó para perpetrar su venganza personal. En todos sus artículos, Quadrado no deja de afirmar, con un lenguaje virulento, que la lucha agermanada no se relaciona ni con la libertad ni con el bien del pueblo, 
sino que tuvo como fin "satisfacer ruines venganzas y de apropiarse de bienes que no les pertenecen". Fundamenta sus argumentos parciales y desde el punto de vista de los vencedores, en documentación inédita: el proceso represivo contra los agermanados mallorquinos, publicado en "Informaciones judiciales sobre los adictos a las Germanías", imprescindible para el estudio de la revuelta (Quadrado, 1896). Pese al contrapunto en sus argumentaciones, en Furió como en Quadrado el alzamiento se presenta como momento clave en el devenir de la isla. Para toda investigación especializada, las obras de Dánvila y Collado y Quadrado tienen una importancia capital, más que por las caracterizaciones que ensayan sus autores, por el invalorable aporte documental, dada la transcripción de escritos oficiales que ambos han desarrollado, con la reproducción de cartas, proclamas, edictos, memoriales, informaciones judiciales, fuentes primarias claves para la indagación de la revuelta.

\section{La producción historiográfica del siglo XX}

La historiografía del siglo XX continúa, en los comienzos, la tendencia cientificista dominante y la revuelta se interpreta como el producto de fuerzas reaccionarias feudalizantes que se oponen al europeísmo liberador de Carlos V. Es el caso de Ballester Julbe, quien desarrolla un aspecto parcial de la revuelta acotado a un sólo foco de conflicto, la ciudad de Xàtiva. Pese a referir a uno de los últimos bastiones de la resistencia agermanada en deponer las armas, el escrito basado en crónica locales y en la obra de Dánvila no posee mayor interés (Ballester Julbe, 2006 [1909]). Habrá que esperar a la etapa de la República, para que la temática de la Germanía adquiera nueva popularidad. Entonces, políticos e intelectuales refieren al fenómeno histórico y su nombre da título a revistas y semanarios, plazas, calles y monumentos. Al silencio, en cambio, las condena el franquismo y se reinstaura la reacción conservadora. Este es el contexto de producción en el que situamos la obra de Luis Redonet, quien postula como causa del levantamiento las "ambiciones y fanatismos (de los agermanados) para satisfacer deseos y pasiones". La Germanía no responde al alzamiento de los gremios sino de "algunos agremiados de horrenda actuación" (Redonet, 1959: 7-16). El autor señala la índole más social que política del caso valenciano y mallorquino: es el "odio de razas" sumado a la "corrupción de costumbres" que llevó al empleo de "procedimientos inhumanos contra nobles, señores y caballeros". Fiel a Dánvila, Redonet descarta como móvil el previo quebrantamiento de fueros, costumbres y libertades. "Los comuneros no fueron liberales, ni héroes románticos sino exclusivistas y rígidos defensores de la política tradicional y nacional contra la innovadora y europea de Carlos V"; tal es su hipótesis y todo otro carácter que se le dé a la revuelta nace en el sentimiento de 1812 cargado de "exabruptos liberaloides". Describe personajes y la participación de ciudades destacando las acciones violentas como escandalosas movidas por la "codicia" y el "egoísta interés personal" de sus líderes (Redonet, 1959: 23-25, 43-50 y 71-75). Destacamos las referencias bibliográficas de esta obra.

Pero más allá de Redonet, en la producción historiográfica local, se destacan una serie de aportes socioeconómicos que pueden ser encuadrados en la llamada "Escuela Modernista", que tuvo por epicentro la Universidad de Valencia, en su sección Historia, a cargo del profesor Reglà, alumno de Vicens Vives, desde 1959. Los inicios de la misma pueden rastrearse a partir de la reconstrucción de los cuadros docentes en la década del ' 40 en la postguerra civil. Es el momento en que nace la revista Saitabi y aparecen nuevos institutos y academias (el Instituto J. B. Muñoz, la Academia de Historia de América, la Academia Valenciana de la Historia en la Real Academia). Es el momento en que se inician los trabajos de restauración de la Iglesia de Sagunto y la excavación arqueológica en Montesa. El órgano de expresión del grupo modernista fue la nueva revista Estudis. En torno a Reglà se desarrolló por tres lustros una 
renovación historiográfica relacionada con las corrientes ultrapirenaicas, especialmente con la Escuela de Annales. Aparece con el modernismo en los estudios valencianos un nuevo concepto de la temporalidad, nuevos sujetos históricos y técnicas estadísticas de tratamiento que se plasman en un programa de investigaciones locales y en exploraciones cuantitativas de series documentales de los siglos XVI y XVII. En la década del '80, el traslado de Reglà a la Universidad Autónoma de Barcelona determinó la decadencia de estos aportes, que, en adelante, se caracterizaron por su fragmentación (Escandell Bonet, 1988: 23-45).

Han centrado su atención sobre la Germanía, en primer lugar, Joan Reglà, cuyas hipótesis generales abrieron el campo de investigación sobre los aspectos materiales de la revuelta (Reglà, 1974: 21-22). La hipótesis acerca del fenómeno agermanado es completamente original; señala que "la Germanía significaría la máxima plenitud de las zonas litorales; y la represión del movimiento agermanado, el reflujo del péndulo, esto es, el triunfo del campo sobre la ciudad, del interior del país sobre las comarcas costeras. Y un siglo después, la expulsión de los moriscos podría considerarse como el movimiento inverso: el triunfo de la ciudad sobre el campo". Abocado al estudio de la problemática de los moriscos en Valencia, el aporte de este trabajo es indudable en tanto intenta pensar el problema de la composición del movimiento en relación con el hábitat. Según el autor, "la Germanía vendría a ser una revuelta de los «oficiales», los cuales ya no encajan bien dentro del monopolio de los gremios. La revuelta urbana entra en contacto con la realidad del campo, que se le muestra adverso y forma un bloque compacto antiagermanado, integrado por los señores, los moriscos propietarios y los moriscos vasallos de la nobleza". Pero tanto la Germanía como la expulsión de 1609 conllevaron a "la consolidación del poderío socioeconómico de la aristocracia terrateniente". Si bien cabría matizar la distribución tajante entre secano y regadío en cuanto al hábitat morisco, la supuesta oposición de la oficialidad en la estructura gremial y el carácter exclusivamente urbano de la revuelta, es indudable que la derrota del movimiento estuvo acompañada por una profunda reacción señorial.

Válida como interpretación general, los discípulos de Reglà profundizaron el estudio socioeconómico de la revuelta. En esta temática, ubicamos la investigación de Castillo del Carpio, destinado a dar cuenta de los problemas surgidos para la financiación del ejército formado por el virrey, desde la óptica de la Diputaciò que colaboró con dicha empresa. El análisis pone de manifiesto la concesión de préstamos "graciosos" a la Hacienda Real para subvenir los gastos de la guerra, pese al control agermanado y concluye con la paradoja que el pueblo valenciano solventó su propia represión (Castillo del Carpio, 1996: 497-515). Juan Vidal y Furió estudian la característica más importante de la economía local preagermanada, de vital importancia para pensar la situación material en la que estalla el conflicto. Nos referimos al sistema de crédito censalista, responsable de una situación de permanente endeudamiento que afectó al conjunto del entramado social; su origen, formas, difusión y el grado de afectación diferencial por actor es estudiado por Furió. El estudio revela su compatibilidad con el sistema feudal, al reforzar el dominio de la nobleza y del patriciado urbano como forma particular de extracción del excedente. El censal permitió una diferenciación progresiva en la base campesina y su gravosidad en términos del endeudamiento público, producto del déficit alimenticio, explica la necesidad de saneamiento y control que intentaron instaurar los agermanados durante el conflicto (Furió, 1993: 501-534). Juan Vidal, por su parte, aporta a la comprensión los aspectos teóricos de su concepción y un análisis exhaustivo de los ingresos y gastos de la época que revelan un círculo vicioso de la economía en torno al censal. Sigue su evolución cronológica desde la aparición del mecanismo hasta la emergencia de la Germanía, considerando al censal no sólo la "premisa desencadenante" del proceso sino el principal "caballo de 
batalla" de los rebeldes. La abolición de los censales fue uno de los mayores puntos de litigio durante la revuelta. Esta investigación es de suma importancia dado que pone de manifiesto la influencia del censal en la sociedad mallorquina, tema que hasta entonces no había sido indagado (Juan Vidal, 1975: 101-158).

A estos análisis de historia económica, deberíamos agregar el estudio de Piles Ros, quien investiga los aspectos sociales de la revuelta. Como buen representante de la escuela modernista, confecciona listas estadísticas con datos inéditos. Menciona los documentos enviados por el virrey a distintas autoridades locales para la confección de nóminas de agermanados como base para imponer castigos económicos y concluye que "la represión apuntaba más a los bienes que a las personas". Piles brinda "noticias" sobre delegados reales encargados de la recepción monetaria, que confirman la extrema necesidad de fondos para sostener las tropas reales y la cesión de bienes por parte de la nobleza local dada "la convicción del peligro que la revuelta entrañaba". Los datos del aprovisionamiento en hombres, vituallas y reales revelan la participación capital del Maestrazgo en la represión del movimiento. La parte documental más interesante es la que refiere al castigo económico de los agermanados que comenzó con la incautación de sus bienes y la subsiguiente venta que buscó resarcir a la corte de sus gastos bélicos. El autor transcribe las relaciones confeccionadas en 1522 que permiten conocer las condiciones de vida, a través de los objetos incautados, de los líderes del alzamiento. Un dato interesante lo constituye la devolución de bienes por restitución de la dote a las viudas de los rebeldes. Señala el autor, dos períodos sucesivos en la represión: el de índole militar y el estrictamente económico que consistió en la imposición de composiciones; Piles transcribe los pagos económicos hechos por individuos, gremios y lugares del reino. Concluye señalando "el marcado carácter económico que se le dio a la represión, la gran extensión que la Germanía tuvo en todo el Reino y la casi total intervención de todos los gremios" (Piles Ros, 1952: 431-478). En sus afirmaciones, Piles tiende a repetir los tópicos del pasado. Descalifica la revuelta como "fondo represado de mal que hay en toda naturaleza, (que) halló ocasión y cauce para manifestarse y desbordarse, tanto más fácilmente cuanto que se hallaba amparado e impulsado por el anonimato de la masa". El autor remarca las debilidades del movimiento, donde "no hay figura que destaque,... nadie sabía exactamente lo que quería; protestaban por vejaciones y ofensas que no se detallaban; sus mismos jurados les recriminaban sus robos; y por lo que se refiere a batallas, propiamente no podemos conceder este nombre a ninguna". La Germanía, revuelta de clases medias y gremios ricos, estaba condenada al fracaso también por su localismo (Piles Ros, 1952: 437-439). El aporte incontrovertible de esta investigación es el pensar la represión como objeto de estudio privilegiado. Sin embargo, si bien se confirma la idea de una reacción señorial a través de la represión económica del movimiento, la relectura de sus datos no revela el protagonismo de ricos artesanos sino el "predominio de los económicamente débiles". Es que Piles no emplea críticamente los datos cuantitativos sobre confiscaciones y composiciones que representaron una oportunidad para incrementar la Hacienda real. En este sentido, es seguro que pagaron más aquellos personajes, gremios y ciudades que tenían mayor capacidad económica y no los que tuvieron una participación más destacada (García Cárcel, 1975: 241-267).

Para el caso mallorquino, otro de los aportes centrales lo constituye el trabajo de Álvaro Santamaría. Su hipótesis es que la Germanía representa "un fenómeno subversivo, a la par guerra civil (dirimida con saña feroz entre mallorquines) y guerra revolucionaria, en cuanto se propuso alterar por la violencia determinados aspectos del orden político y socioeconómico existente, y situóse con ello abiertamente al margen de la ley" (Santamaría, 1971:25-40, cita en p. 27). Santamaría parte del análisis de los "factores de base" en Mallorca que propiciaron el alzamiento y señala por tales: la tensión ciudad-villa como factor estructural de gravitación secular y el asunto de la deuda pública no resuelto desde 1405 . La coyuntura agermanada es caracterizada 
por: 1) "una crisis de autoridad que se produce tanto en la Corona de Castilla como en la de Aragón en 1516 a la muerte de Fernando el católico, en la interinidad de la regencia y el advenimiento de Carlos I"; 2) "la sacudida subversiva al amparo de la crisis en 1519-1520 en la Península"; 3) "la degradación de la autoridad en Mallorca como reflejo de la crisis del orden público y derivada de las rivalidades que separaban a las autoridades insulares"; 4) "la organización de los gremios en Mallorca" que conforman entidades efectivas para el amparo de los menestrales; 5) "la concurrencia de los hechos referidos, sobre todo la generalización del ambiente subversivo en la Península"; factores que indudablemente propiciaron el conflicto. Cerramos este apartado considerando la hipótesis de Fuster acerca del carácter de la Germanía: las mismas, señala, "fueron, tanto en el País Valenciano como en la isla de Mallorca, algo más que una simple revuelta popular: fueron, de hecho, un intento de eso que en términos modernos podríamos llamar revolución". Ya en Nosaltres els valencians, el autor señalaba como en los inicios del siglo XVI se asiste en Valencia a un "recrudecimiento" de las tensiones sociales, donde las capas inferiores ingresan en una "fase de excitación agresiva". La formación de las milicias conllevará naturalmente a la gestación de una acción directa contra la tiranía de los nobles. "Las Germanías -escribe Fuster-fue estrictamente una guerra civil entre los nobles y el pueblo", cuyo fracaso no minimiza el mérito del propósito. Indaga el ejercicio agermanado de gobierno ciudadano y la extensión como "rabia social" por el campo. Distingue la actuación de sus líderes en función de sus orígenes sociales y finalmente, apunta las represalias que el movimiento tuvo por una "represión brutal y vergonzosa" (Fuster, 1992). Pero más allá de estos perfiles de lucha insertos en un libro sobre la historia valenciana que ha conocido varias reediciones, años más tarde se dedica específicamente a escribir sobre la revuelta. El trabajo es el primero que toma el fenómeno agermanado en todos sus aspectos ideológicos; como marxista, incorpora las categorías de clases sociales modernas para el análisis de una revuelta que representa la "lucha de los menestrales y de un sector de la burguesía contra las oligarquías tradicionales por el dominio de las instituciones del municipio" y "el alzamiento de los campesinos contra los señores territoriales". En este sentido, se pone de manifiesto una pretensión igualitaria democrática. Al tomar en cuenta el alzamiento rural de la Germanía y su programa, las ideas de Fuster resultan claves para el abordaje también de la segunda etapa del conflicto. Destaca el carácter republicano del movimiento dadas sus "raíces eiximinianas" con la adopción del modelo de "las comunas italianas sin monarcas ni aristócratas". Examina el fenómeno de los bautismos forzosos de moriscos, el cual interpreta como un hecho de corte revolucionario, ya que fueron un "intento de cambio de las condiciones políticas y sociales por la resultante emancipación", dado que los moros representaban una "competencia desleal en el mercado de trabajo" y su conversión quebró definitivamente las relaciones sociales feudales. Es de particular interés el análisis del personaje del Encubierto "como expresión de igualitarismo social" en la revuelta. Fuster acierta a inscribir el análisis de esta figura como expresión de una cultura no escrita entre clases sociales descalificadas y mayoritarias (Fuster, 1972).

\section{Las principales tesis sobre el caso agermanado}

En las últimas décadas del siglo XX, producto del nuevo interés de historiadores, sociólogos y politólogos por el conflicto social, las revueltas y las revoluciones, en definitiva, a partir del "retorno del sujeto", han aparecido las tesis doctorales más significativas acerca del caso agermanado: en los '70, el estudio de Ricardo García Cárcel; en los ‘80, el análisis de Eulàlia Durán y en los ‘90, el aporte de Vicent Vallés Borràs. El estudio pionero en la materia indaga el fenómeno en sus aspectos geográficos, sociológicos y etiológicos, luego de analizar sus condicionantes estructurales políticos, económicos y culturales y sus precipitantes coyunturales, en base al método 
7. Reeditado en 1981 cuando suaviza los aspectos esquemáticos del método de Stone. propuesto por Stone (García Cárcel, 1975). ${ }^{7}$ Su tesis que permanentemente somete a revisión (la última data del año 2000) resulta clave para el análisis de la Germanía: señala el autor que la revuelta "fue en gran parte consecuencia de la pugna entre la sociedad descentralizadora medieval, frente a la centralización que imponía el absolutismo del cesarismo naciente. Sabido es, además, que la política monárquica era casi siempre librecambista y favorable al mercantilismo extranjero. La progresiva alineación de la monarquía de Carlos V con el capital alógeno empobrecía más y más cada día a unos anquilosados gremios tradicionalistas, incapaces de acomodarse a los nuevos planteamientos económicos y políticos". La seguridad del hombre agremiado se ve rota en esta transición del feudalismo al capitalismo de "tipo francés" que determinaba el individualismo y la despersonalización de las relaciones humanas; el desasosiego sumó a artesanos y pequeños burgueses en el odio a la nobleza y los llevó a exigir la rectificación real.

El historiador asegura que la Germanía estalla en un contexto marcado por ciertas condiciones económicas sociales locales, pero descubre condicionantes políticos de carácter nacional en el absolutismo monárquico de Carlos I y la generalización de la corrupción. Refiere también a las condiciones culturales analizando la literatura de la época y, a estos elementos, el historiador español suma la descripción de la coyuntura: el fenómeno de la hipertensión social, producto del desequilibrio económico que agrava el problema del desabastecimiento triguero y el fenómeno de la "alienación mercantil". Es de sumo interés el planteamiento de los rasgos ético-religiosos que asume esta tensión social. En una "morfología de la revuelta", describe la cronología y el enfrentamiento militar, al que caracterizan, según el autor, tres rasgos: la pésima dirección agermanada, la falta de clarificación de objetivos y la mortandad del bando agermanado. Destaca nuestro autor la represión económica de la virreina Germana de Foix, que permite una refeudalización al servicio real camuflando las contradicciones del sistema que llevaron al alzamiento. Es de suma importancia el análisis de la estructura de la revuelta. García Cárcel confirma el enfrentamiento entre el litoral y el interior y, en lo sociológico, el predominio de los maestros gremiales, campesinos, el clero bajo y escasos sectores burgueses. El doble carácter de la Germanía (en parte revuelta de la miseria, en parte revuelta de la prosperidad) determinaría el fracaso del movimiento, dada la trayectoria agermanada marcada por profundas contradicciones: de origen entre el legalismo con el que nació el movimiento y "las lógicas transgresiones de la legalidad en las que la evolución revolucionaria llegó a incurrir"; y de naturaleza, "por ser una revuelta antifeudal sin burgueses". Discute por último las consecuencias de la revuelta en el plano económico social, cultural e ideológico y concluye conceptuando a la Germanía "como una híbrida manifestación contestataria en la que se mixtifican elementos de rebeldía primitiva, indicios de revuelta y algunos síntomas de auténtica revolución" (García Cárcel, op. cit.: citas en p. 8-9 y 240). La dureza tanto en la calificación del accionar agermanado como en la oposición que ensaya con el caso comunero, será luego revisada por el autor, remarcando su carácter revolucionario (García Cárcel, 2002: 209-230).

Habrá que esperar hasta los '80 para encontrar un aporte tan significativo como el que hemos reseñado. Se trata de la tesis doctoral que defendió en la Universidad de Barcelona Eulàlia Durán. La labor de la historiadora moderna resulta clave para quienes abordan el estudio de la Germanía, ya que contextualiza la revuelta en el marco de los Países Catalanes, analiza la cuestión profética en estos reinos y, como compiladora, produjo la invalorable publicación de importantes fuentes primarias. En este último aspecto, es de destacar la edición de las crónicas coetáneas a los sucesos de Catalá y Garcia, en lengua valenciana, fuentes primarias y principales de la revuelta (Durán, 1984). Su libro más importante dedicado a la Germanía, escrito en catalán, reconoce un repertorio bibliográfico completo, al cual continúa una investigación que comienza por poner de manifiesto la evolución demográfica de los países catalanes 
en su conjunto durante los siglos XV y XVI y particularmente las repercusiones del conflicto en términos poblacionales. Se postulan las crisis y tensiones del período preagermanado desde 1472, pasando revista a los conflictos generales, las políticas municipales y el problema de la deuda pública (Durán, 1982: 47-140). Pero es la tercera parte de su libro la que ofrece mayor interés dado que la autora parte del advenimiento, expansión y desarrollo del conflicto armado en la cabecera valenciana para adentrarse en las alteraciones en las cabeceras catalanas (Lleida, Barcelona, Girona) y en los sucesos acontecidos en Mallorca. ${ }^{8}$ Durán afirma que la revuelta afectó a todos los estados de la Corona catalano-aragonesa con distinto nivel de intensidad, aún cuando no derivó en una organización general de carácter orgánico. Los objetivos del movimiento fueron el control municipal y la supresión de derechos. El panorama global y particularizado de la revuelta se completa con un análisis de la represión y situación subsecuente y una conceptualización acabada del conflicto social. Su tesis es que la Germanía fue una revuelta devenida en revolución, dado el intento de un estamento marginado de los cargos políticos por acceder al gobierno municipal en detrimento de las clases privilegiadas, invirtiendo la estructura estamental. Una revolución medieval por los problemas planteados y las formas con las que intentan resolverlos, pero también moderna dado el intento agermanado no sólo de intervenir sino de gobernar en forma exclusiva. Es central su explicación acerca de la adhesión de las villas foráneas en Mallorca como de las poblaciones señoriales en Valencia. En opinión de la historiadora, es la composición social del movimiento, integrado por menestrales dedicados principalmente al tejido y la confección y de "payeses" con exclusión de las clases privilegiadas, la que explica el carácter original de la Germanía (Durán, op. cit.: 364-419).

La obra de Eulàlia Durán no sólo resulta de particular importancia para la indagación de la Germanía por la autoría del libro mencionado, síntesis de su tesis doctoral. También apuesta a desarrollar en sus estudios una recuperación del clima profético en el que se sitúa y encuentra significado el ideario agermanado. Así, la autora delimita una particular y prolífera línea de investigación historiográfica sobre la revuelta, poniendo de manifiesto "los aspectos milenaristas que impregnaron la ideología de los rebeldes, la justificaron y la cohesionaron" (Durán, 1995: 21-29). La práctica agermanada se halla marcada por la influencia de estas creencias milenaristas y aparece en su análisis como la razón última que explican sucesos tales como el bautismo de los moriscos o la emergencia del mesiánico Encubierto durante el conflicto. Durán remarca fuertemente en esta caracterización el "clima profético o fervor religioso" que anima a la revuelta como fundamental para la comprensión del antagonismo social, clima que tiñe las reivindicaciones ideológicas de ambos bandos, donde los antiagermanados se inclinan hacia una apología del estamento nobiliario, la condena del alzamiento y la exaltación de la fidelidad real (Durán, 1982: 53-68). Junto a su alumno Joan Requesens, Durán ha publicado una antología de textos proféticos catalanes, en el cual se destaca el tratado De la venguda d'Anticrist de Joan Alamany, impreso originalmente en Valencia en 1520, escrito de profunda influencia en los rebeldes (Durán y Requesens, 1997).

Finalmente, Vallés Borràs en los ' 90 aborda el estudio completo del programa de reivindicaciones y brinda elementos fundamentales para la comprensión de la dimensión política del conflicto. El historiador estudia la revuelta agermanada, centrando especialmente su atención en su programa reivindicativo, a partir de la recuperación de la documentación original emanada de la Junta de los Trece, dirección del movimiento rebelde. Señala que el objetivo último de la Germanía, a la luz de su programa, fue la constitución de un nuevo "estamento popular". Es clave la justificación política de los alzados ante el rey, no bajo la forma de unión o hermandad que presupone una acción resistente o rebelde sino bajo la figura del adehenament que prescribe el ordenamiento real; haciendo uso de este recurso,
8. Si Durán revela la influencia de la revuelta sobre el Reino de Mallorca y el Principado de Cataluña, la historiografía especializada ha dado cuenta también de las influencias sobre los territorios del Reino de Aragón. Ver por ejemplo: Vallés Borràs (2008: 491-504). 
9. La actuación de los abogados agermanados fue abordada particularmente en: Vallés Borràs (1996: 203-226).

10. A modo de ejemplo sobre estos distintos acercamientos: Pérez García (2006: 311-332). los populares trataron de lograr obtener concesiones para denunciar o reparar las injusticias existentes (Vallés Borràs, 1990). En su libro, La Germanía, trata los fundamentos ideológicos, los aspectos organizativos y la expansión y ocaso del movimiento a partir de la documentación notarial proveniente del vaciado de protocolos existentes en los archivos valencianos. Las premisas del programa reivindicativo estructuran su trabajo y permite el "conocimiento de una sociedad utópica en pleno Renacimiento a cuya construcción dedicaron sus esfuerzos unos artistas y menestrales unidos por el juramento agermanado". Así, trata los orígenes donde alude a los hechos y factores que precipitaron su existencia; la organización donde refiere a los cargos gubernativos creados y adscriptos al movimiento y sus acciones en torno a la administración de justicia; la estrategia militar y divisiones políticas al interior del bando rebelde; finalmente, aborda las interrelaciones entre la Germanía y la Corona, el municipio y el bando nobiliario-morisco (Vallés Borràs, 2000: 12).

Vallés Borràs logra en su investigación una sólida aproximación a la temática menestral que se halla en el centro de la problemática social que dio origen a la revuelta. En la misma y entre los distintos artículos especializados que le ha dedicado, pondera también la decisiva actuación de los abogados agermanados Bertomeu Monfort y Jerónimo Soriano, fieles exponentes del bando moderado del alzamiento. ${ }^{9}$ Basado en documentación notarial y criminal que contrasta con las crónicas coetáneas a los sucesos, el autor expone los planteos reivindicativos, la gestión, organización y actuación militar de un movimiento social, cuyo paso del adehenament a la germandat significó la adopción de posiciones subversivas y la organización de una "clase popular" en una confederación que incluyó territorios foráneos. El historiador señala la incidencia para el derrotero de la revuelta del quiebre del movimiento entre radicales y moderados, afirmando que se halla en dicha división las claves del fracaso. Escribe que "se malogró la ocasión de regenerar el sistema foral valenciano mediante la integración en la organización política de una burguesía con clara conciencia de su poder económico, pero que no fue capaz de calibrar las repercusiones de su unión con unas clases populares que, sumidas en una compleja crisis social y económica, consiguieron desbordar el marco foral, arrastrándoles, mediante la violencia a la rebelión" (Vallés Borràs, 2008: 282). Si bien, en nuestra opinión, donde Vallés Borràs encuentra el fracaso de la acción política agermanada, en la lógica situacional no podemos dejar de pensar que se halla la importancia y trascendencia de la revuelta, es innegable que sin esta problematización del bando rebelde que ha ensayado acabadamente el autor, no podrá ser abordado en lo sucesivo el estudio del conflicto social.

\section{Los aportes recientes al estudio de la revuelta}

Las tesis mencionadas han renovado el interés por los sucesos agermanados. La producción local se ha multiplicado en los últimos tiempos y cabe mencionar en primer lugar a Pérez García, con múltiples aproximaciones al caso. ${ }^{10}$ Sus estudios y contribuciones documentales sobre la justicia criminal antes, durante y después de la revuelta, constituyen un punto de partida indudable para el análisis de la dinámica política de la Germanía. De la prolífera producción de este autor, destacamos tres contribuciones centrales. La primera es el artículo publicado en la revista Estudis donde examina el papel de la justicia penal durante el conflicto agermanado. Su práctica, señala Pérez García, no puede limitarse a la idea de una persecución de contrarios o represión de alzados. Por el contrario, la justicia fue bandera reivindicativa, instrumento de defensa y engranaje más complejo que los "tumultos" que en Valencia enfrentaban a la plebe y al patriciado. La justicia penal que exhibe este antagonismo comparable al modelo romano, le permite abordar al historiador el 
estudio de las reivindicaciones políticas del conflicto social. Brinda un relato detallado de los sucesos, de las estrategias punitivas y del ejercicio de la justicia, incluyendo el abordaje de "la Germanía radical y semiclandestina", sus líderes y acciones políticas (Pérez García, 1996: 141-198). Terminada la revuelta, permanece la sombra del Encubierto, el líder de la resistencia agermanada, sobre la historia valenciana. Sobre este tema, destacamos de Pérez García el estudio preliminar en coautoría con Jorge Antonio Catalá Sanz que precede a la publicación del sumario y sentencia llevada a cabo en Valencia durante el año 1541 contra los partícipes de la considerada última conspiración encubertista. En dicho estudio, se recapitulan todas las hipótesis e informaciones relativas al personaje, provenientes de crónicas, sumarios e investigaciones históricas, y se inserta su comprensión como fenómeno mesiánico global que trascendió los límites temporales del conflicto (Pérez García y Catalá Sanz, 2000). Caracteriza al encubertismo como movimiento sectario, condicionante del radicalismo agermanado, y la emergencia pública del personaje histórico el 21 de marzo de 1522 como "golpe de estado" interno a la revuelta, que subvierte la resistencia y el radicalismo político popular; interpretación clave para pensar el ciclo de acción colectiva (Pérez García y Catalá Sanz, 2000: 140-174). Finalmente, mencionamos acerca de la producción de Pablo Pérez García su estudio de la criminalidad y ejercicio de la justicia urbana en la Valencia preagermanada. Fundamental por brindar una caracterización detallada del fenómeno de los "malhechores" urbanos en el contexto situacional (Pérez García, 1990). El procedimiento judicial es concebido en su enfoque "como espejo de las preocupaciones, valores y categorías de pensamiento social en torno a la violencia". En este sentido, detecta en el contexto preagermanado la generalización y democratización de la posesión de armas, la existencia de una sociabilidad conflictiva y la emergencia de "guerreros plebeyos" que a la postre serán líderes del movimiento agermanado en su fase radicalizada. Estos últimos no son sólo expresión de un ideal de igualdad de las capas artesanas y campesinas valencianas, señala Pérez García, sino que emergen como aspiración popular al ejercicio efectivo de los derechos de violencia que ostentaba entonces la nobleza. La criminalidad es la misma línea de investigación en torno al fenómeno que ha elegido Narbona Vizcaíno para dar cuenta de la problemática del adehenament (Narbona Vizcaíno, 2006: 305-332). El historiador estudia la presencia de "malhechores" en la sociedad valenciana medieval; este grupo conformará las milicias ciudadanas en la modernidad y señala que el desencadenamiento de la Germanía debe entenderse a partir de este convulso panorama político-social caracterizado por la lucha de bandos. Define la revuelta como "movimiento constitucionalista que abogaba por las libertades forales como por repristinar el justicialismo regio". Encuentra antecedentes de la lucha agermanada en la Guerra de la Unión y la militarización social. El autor resalta la importancia del paso del "adehenament" al "agermanament", prohibido por los fueros, que encausa las reivindicaciones contra la clase dirigente valenciana. Narbona Vizcaíno destaca, finalmente, la importancia de los alardes tanto en la Valencia preagermanada como durante el conflicto.

De excepcional importancia son las contribuciones enderezadas a dar cuenta de la represión desplegada al término del alzamiento. La tesis doctoral de Pinilla Pérez de Tudela aborda el estudio de la actuación para la reorganización posagermanada de los virreyes valencianos doña Germana de Foix y Fernando de Aragón, duque de Calabria, entre 1526 y 1536, a través del relevamiento de la documentación de la Cancillería Real del Reino de Valencia que completa con otras series documentales. Analiza tanto el contexto situacional marcado por el fin del conflicto y el inicio de la "cuestión morisca", determinantes de la historia local posterior, así como también la institución virreinal en sí misma y en su ejercicio que limita las atribuciones del funcionario a simple ejecutor de las decisiones tomadas en la corte. Conforme a estos objetivos de investigación, desarrolla un análisis acabado de los castigos impuestos a los agermanados confirmando el carácter marcadamente económico que adquirió la 
11. A modo de ejemplo destacamos: Pardo Molero (2004: 583-606).

12. Estos clásicos artículos formaron parte de su investigación general: Benítez Sánchez Blanco (2001). represión nobiliaria y real (Pinilla Pérez de Tudela, 1994). Igual que Pinilla pero sobre los alcances de la represión en Mallorca resulta de interés el estudio cuantitativo de Vaquer Bennassar. El mismo precisa las zonas más afectadas de castigo económico y el alto grado de ejecuciones que convierten a la represión de la Germanía mallorquina en la más cruenta en comparación con la de los conflictos coetáneos desarrollados en los territorios de la monarquía hispánica (Vaquer Bennasar, 2000: 57-71).

Trascendiendo el fenómeno represivo, el objeto de estudio de la tesis y del principal libro de Juan Francisco Pardo Molero se encamina a pensar la defensa y la guerra en el Reino de Valencia bajo Carlos I, la dimensión militar en el contexto mediterráneo (Pardo Molero, 2001). Aborda para ello el estudio de la organización defensiva del reino, a partir de una continua "negociación" entre monarquía y poderes locales, transformándose en un retrato de las tensiones de poder y condiciones militares del Mediterráneo Occidental durante la primera mitad del siglo XVI. Ensaya una periodización de estas tensiones que describe los siguientes momentos: el primero desde los inicios del reinado hasta la revuelta, un segundo período que dedica a la "guerra de Germanías" y que denomina de tal forma, seguido de dos períodos, de 1533 a 1544 cuando se desarrolla la defensa frente a la ofensiva armada turca y de 1544 a 1555 cuando la organización defensiva se plantea en un contexto de marginación del frente mediterráneo en la estrategia imperial hasta la crisis del proyecto carolino. El segundo momento que describe Pardo Molero está marcado por la configuración de los frentes de guerra en 1521, la capitulación de la ciudad de Valencia, el fin de la guerra en 1522 y el surgimiento de una conflictividad morisca desde la insurrección de la Sierra de Espadán en 1526 (Pardo Molero, 1997-1998: 113-154). El autor indaga "la frontera" y "la cruzada", palabras claves para el contexto situacional y explicativo de la revuelta, síntesis del proyecto imperial y de su fracaso, motivo de impugnación social por sus dificultades e inconsecuencias (Pardo Molero, 2000: 114-131). Es que el historiador concibe a "la guerra como constructora de identidades" y señala la "reactualización y uso continuo de identificadores de la Reconquista" en la historia local donde "la defensa adquiere un efecto dinamizador e integrador" de la comunidad política; conceptos de particular importancia para conceptuar el comportamiento agermanado (Pardo Molero y Ruiz Ibañez, 2007: 429-466). En distintos artículos, despliega una prolífera investigación acerca de los costos de la asunción del proyecto carolino, su legado militar, las distintas formas de fortificación ensayadas y proyectadas en la época, su problemática en términos del financiamiento, el sistema de exportación de guerra y el desarrollo de una política errática entre la represión y la tolerancia hacia los moros. ${ }^{11}$

Sobre precisamente la cuestión morisca, resulta de capital importancia el análisis de Benítez Sánchez Blanco sobre los episodios de violencia política. Dos artículos publicados en la revista Estudis se hallan dedicados al estudio del papel del miedo en el conflicto agermanado, al analizar en el primer escrito su impacto en los moriscos durante el verano de 1521 dada la ejecución de los bautismos forzados por los rebeldes (Benítez Sánchez Blanco, 1996: 27-52). El siguiente artículo aborda las tensiones que generaron esta conversión forzosa en la vieja sociedad y entre los nuevos convertidos, sus antiguos correligionarios y los señores, situación que explica la presión nobiliaria para la vuelta a la situación religiosa previa a la revuelta (Benítez Sánchez Blanco, 2000: 11-36). La lectura de ambos artículos permite concluir que la perseverancia en la fe estaba plenamente vinculada al grado de avance del movimiento agermanado, así como su retroceso debe asociarse con el retorno a los antiguos credos, a la "vida de moros", con la protección de la élite y pese al rechazo popular que revelan los distintos testimonios de la época. ${ }^{12}$ El historiador emplea como fuente el informe elaborado por Alonso Manrique en noviembre de 1524 sobre la forma de los bautismos agermanados para el establecimiento de su validez canónica que finalmente se estipuló en 1525 , en base a la recolección de testimonios de los habitantes de las comarcas 
centrales del Reino. Entre los elementos salientes incorporados por Benítez Sánchez Blanco, debemos destacar el cuestionamiento al "mito historiográfico" de las acequias y palos de escoba en cuanto a las formas del bautismo agermanado y su estudio detallado del marco espacial de esta empresa religiosa-política, estableciendo una verdadera "geografía de las conversiones". Finalmente, explica los móviles de la acción agermanada e incluso su aceptación por parte de los moriscos en base a la "mentalidad de la época impregnada de milenarismos", una forma de reacción contra los miedos postulada por Delumeau (1989).

Estos ribetes milenaristas de la revuelta, profusamente estudiados por Eulàlia Durán, han concitado la atracción por especialistas que trascienden el marco de la historiografía peninsular. Un trabajo pionero en el estudio del clima profético en la monarquía hispánica pertenece al francés Milhou, quien analiza la adopción desde fines del siglo XIII por la Corona de los ciclos proféticos que circulaban por Europa y el rol que cumplieron los franciscanos catalanes influenciados por el joaquinismo y los espirituales. El autor se propone reconstruir en su artículo la evolución de las tres imágenes aplicadas al emperador de los últimos tiempos: el vespertilio, el nuevo David y el Encubierto, esta última de particular importancia en la revuelta agermanada. Particulariza la situación de Cataluña y la política desplegada por los reyes de Aragón y, en este sentido, afirma que el mesianismo ibérico nació de una doble herencia franciscana-joaquinita e imperialista en los países catalanes por la instrumentalización de los reyes de Aragón (Milhou, 1982: 61-78). También Martín Aurell refiere la importancia de la profecía como arma política de la Corona aragonesa desde fines de la Edad Media y el contenido ambivalente de los textos apocalípticos. Tras el uso político de la profecía, se afirma -señala- una "identidad nacional" primitiva en los territorios de la confederación (Aurell, 1997: 119-155). Nalle, historiadora norteamericana, intenta explicar el motivo de atracción histórica por el Encubierto, pese al escaso tiempo de protagonismo en la revuelta y al silencio de los cronistas sobre su figura como sobre el propio conflicto. Trata de trascender la oscuridad y hostilidad de los cronistas hacia dicho personaje por acceso a "su propia voz" y efectúa un análisis del discurso pronunciado en la plaza de la Seo, que reconstruye a través del proceso inquisitorial, cuya eficacia en términos de su recepción la encuentra en la preparación social que supuso la difusión del texto de Alamany, De la venguda de Antichrist (Nalle, 2002: 77-92).

En esta problemática y para el caso mallorquino, debemos sumar el aporte de Serrá, quien señala la invisibilidad que la ideología del movimiento ha tenido en la historiografía de la isla y rescata la producción escrita mayormente manuscrita proagermanada, dispersa en tratados, poemas, sermones y profecías. A partir de esta producción afirma que la revuelta fue concebida como un acto de justicia popular, imbuido de una ideología antimonárquica, construida por notarios, clérigos y ancianos. A la mentalidad reivindicativa, suma los componentes milenaristas de raíz cristiana y particularmente los originados en el pauperismo franciscano; un cristianismo más popular que ortodoxo y muy cercano a la heterodoxia. Concluye señalando el papel de la profecía en el contexto local, un género característico del conflicto político durante todo el Antiguo Régimen, poniendo de manifiesto una particular interpretación de algunas de estas piezas proféticas (Serra, 2004: 565-578).

Hauf i Valls ya en la historiografía valenciana dedicó varios estudios a la cuestión apocalíptica y milenarista. Indaga la cultura medieval local desde Eiximenis a Sor Isabel de Villena, personalidades de fuerte influencia profética cuyos escritos resultan ser reveladores de significativas cuestiones políticas y sociales. Particularmente Eiximenis, pensador político catalán, es la figura de mayor relieve e influencia en la vida política valenciana, dada la difusión de sus ideas que fueron ampliamente aceptadas por la clase dirigente y serán mucho después empleadas por los agermanados contra el orden 
vigente (Parma, 2002, Tomo V: 39-68). Hauf analiza el edificio doctrinal, las técnicas y la procedencia de las fuentes empleadas por el autor para determinar la originalidad de su doctrina. Además del aporte de una biografía documentada sobre las obras y el derrotero personal de Eiximenis, Hauf expone la "teoría pactista eximiniana" que responde a la tradición catalana a la cual pertenecía el escritor y analiza los múltiples recursos practicados (narraciones intercaladas, proverbios, conclusiones didácticasmorales) en los que halla la clave de su perduración e influencia en el escenario político posterior (Hauf I Valls, 1990).

Importantes contribuciones historiográficas se hallan destinadas a dar cuenta de distintos aspectos en el plano de las instituciones valencianas de la época, como los estudios de Pilar Valor Moncho sobre el Consell municipal, de Febrer Romaguera acerca de la participación de la Universidad o los trabajos de Amparo Felipo Orts sobre las relaciones con la Corona. El libro de esta última autora estudia particularmente las oligarquías urbanas de la época foral moderna a partir del caso valenciano y detecta un reforzamiento de la autoridad monárquica desde el Rey Católico sobre el municipio, al cual continúa un período de reacción local marcado por el vacío de poder y la debilidad política de Carlos I, que es el contexto en el que surge y del cual se nutre la revuelta agermanada (Felipo Orts, 2004). Analiza el creciente proceso de oligarquización del gobierno municipal, las modificaciones institucionales agermanadas que demuestran, en su opinión, el moderantismo del bando rebelde y las tensiones entre el poder local y la Corona dado el intento de control real sobre los oficios, línea que se refuerza tras la derrota de la revuelta. Felipo Orts caracteriza el entramado institucional, ofrece datos cuantitativos acerca de esta tendencia a la concentración de cargos favorecida por el rey y recrea trayectorias políticas, empleando como fuente el Manual de Consell (Felipo Orts, 1996: 59-93). En el derrotero de los cargos institucionales, se destaca su análisis sobre la figura del síndico, cargo principal en el organigrama municipal de la época foral, cuando se asiste a una fuerte disputa por su control entre el Consell y la Corona que pese a sus intentos de injerencia no logró controlar su nombramiento (Felipo Orts, 2001: 51-78).

Pilar Valor Moncho también centra su atención en la historia política institucional valenciana a través de la revisión de la documentación existente en el Archivo Municipal de Valencia. Aborda el estudio de la Germanía desde el punto de vista de las resoluciones provenientes del Consell General en manos de los rebeldes. Califica el movimiento "como punto máximo del intento de los consejeros de desposeer a los jurados del poder de nombrar, elegir y revocar oficiales de la ciudad" (Valor Moncho, 2000: 227-242, cita p. 235). Acerca de la situación previa, detecta el alto grado de tensión existente por la dirección del municipio y el fuerte intento de superar el intervencionismo regio que significó la revuelta. Intervencionismo real que remonta hasta los Trastamara y que no se inicia con Fernando el católico como argumenta Felipo Orts. Valor Moncho demarca tres etapas del conflicto social, haciendo hincapié en la intermedia marcada por el dominio agermanado del Consell hasta la guerra cuando los consejeros enderezan sus esfuerzos hacia la pacificación. En otro de sus artículos dedicado al estudio del Consell General, ratifica el moderantismo que caracterizó la actitud del organismo en el transcurso de la revuelta, cuando adquirió un importante papel en el gobierno de la ciudad y señala el elevado número de miembros que entonces lo integraba con una amplia presencia del elemento menestral, particularmente del sector textil (Valor Moncho, 2001: 11-38). En su apuesta por seguir la revuelta desde el punto de vista institucional, relata los sucesos relativos a las embajadas ante el rey, las reformas municipales, medidas económicas adoptadas y los intentos por evitar la guerra. Completa su trabajo un análisis sobre la procedencia socioeconómica, grado de asistencia y comportamiento de los consejeros de 1515 a 1523 y una descripción y síntesis de la evolución de los órganos de gobierno de la ciudad (Valor Moncho, 2000: 227-242). 
Pero el análisis institucional de la historiográfica local reciente no se limita a la indagación de la actuación de las instancias gubernativas. Un buen ejemplo son los estudios centrados sobre la relación entre la revuelta y la evolución de la Universidad de Valencia, del Estudi General, que constituye materia de indagación aún no lo suficiente explorada por autores tales como Manuel Vicente Febrer Romaguera. El autor señala la escasa intervención de la Germanía en la configuración del claustro universitario y la exigua identificación del estamento doctoral con el movimiento. La revuelta opera en este sentido cambios institucionales que ponen de manifiesto los problemas existentes desde su fundación con una acusada reivindicación autonómica frente a la patrimonialización municipal que intenta preservar sus privilegios en el control universitario (Febrer Romaguera, 1996: 25-52). Detecta en el transcurso del conflicto alteraciones de la vida académica, disputas y un intento reformista agermanado bajo la gestión del rector Joan Andreu Strany. La represión a los rebeldes determinó su huida y destitución y la suspensión de la actividad académica no avalada por el total de los catedráticos y maestros. Sin embargo, el autor señala que ningún integrante del claustro universitario fue procesado por su participación en el conflicto, poniendo en evidencia el desinterés por la revuelta del Estudi General (Febrer Romaguera, 1998, Tomo I: 125-140).

Los últimos estudios sobre la Germanía se hallan enfocados a dar cuenta de los alcances de la revuelta en determinadas regiones y ciudades del reino, a través de una detallada exhumación de archivos locales donde aún permanecen fuentes inexploradas. Si bien los estudios localistas no han producido conclusiones que contradigan las líneas generales de interpretación del caso agermanado, contribuyen a sumar importantes elementos en torno a las características particulares de la acción en el conflicto. Entre estos trabajos, merecen destacarse el de Agustí Soler sobre la Gobernación de la Plana, el de María José Gimeno Roselló sobre Paterna o la indagación sobre los conflictos jurisdiccionales en torno a la ciudad de Oriola que revela el trabajo de Carrasco Rodríguez y que explican la batalla y el saco posterior, episodio clave en la evolución cronológica de la Germanía (Gimeno Roselló, 1995; Carrasco Rodríguez, 1999: 219234; Agustí Soler, 2002). La mayoría de los autores mencionados han construido en torno a la revuelta sus respectivas tesis doctorales, en el marco por lo general de la Universidad de Valencia, confirmando la vigencia del movimiento como objeto de estudio capital para la historiografía local.

Entre estas contribuciones, damos término al recorrido historiográfico con los análisis, ya clásicos, pero que consideró los de mayor esfuerzo interpretativo para una exégesis de las acciones rebeldes. Me refiero a la investigación doctoral de Vicent Terol i Reig que lleva por título "Un regne sense cavallers? La Germania en la sotsgovernació de Xátiva" y que fuera defendida ante la institución valentina en diciembre de 2002. ${ }^{13}$ El historiador analiza la revuelta en el marco de la "primera crisis del sistema feudal" y por ese motivo relaciona su desarrollo con los sucesos comuneros y los acontecimientos de Cataluña y Baleares. También ofrece una perspectiva diferente de análisis del caso agermanado que aborda, no desde la ciudad, sino desde el país valenciano, su estudio y centra su atención en la gobernación foral de Xàtiva. Así, se aproxima al aspecto más descuidado por la historiografía como es la "vertiente rural y antifeudal" de la Germanía. Su reconstrucción sociológica a fin de explicar la participación, siguiendo el derrotero de las trayectorias individuales y basada en la exhumación de los archivos locales comarcales, revela una mayor complejidad del antagonismo social y pone al descubierto el proceso de polarización política que el conflicto alumbró. El estudio de Terol no deja de ser un análisis de historia local que incluso se transforma en estudio de microhistoria para el caso del valle de Albaida, región particularmente afectada por la Germanía. La guerra y la segunda fase de la revuelta cobran una importancia que no es común de observar en otros estudios especializados. Es clave la distinción entre radicales y moderados en función de sus "diferentes expectativas
13. Un resumen de esta tesis se encuentra publicado por la revista Estudis (Terol I Reig, 2002: 509-520). 
14. La violencia política previa y durante la revuelta en: Terol I Reig (1999: 41-56; 2009: 9-14). de cambio" y el tratamiento estadístico de las "militancias" y sus matices que propone para una de las cabeceras de la gobernación. Es el caso de Ontinyent que el autor ha estudiado acabadamente gracias a la disponibilidad del acervo documental conservado en los archivos locales, tal como lo pone de manifiesto el artículo publicado en la revista Afers sobre la disidencia política y la contestación popular en la villa marcadas por el fenómeno social agermanado (Terol I Reig, 2005: 653-668).

"Contra cavallers i en defensa del Reial Patrimoni" es el título que eligió Terol para otro trabajo, publicado en una obra colectiva destinada a pensar la relación entre Valencia y la Corona bajo Carlos V. La trascendencia de la revuelta queda expuesta en dicho análisis que parte de la consideración del período transicional de 1516 a 1519. Define a la Germanía como "movimiento sociopolítico protagonizado por menestrales, artistas y labradores de la ciudad de Valencia y de la mayoría de las poblaciones de realengo y por un abanico sociológico más complejo en las de señorío". Terol plantea entre los móviles de la acción la presencia de conflictos jurisdiccionales que responden a una ofensiva de una "belicosa nobleza" en crisis financiera y que desencadena movilizaciones que comprometen la paz del reino. Su objeto de estudio lo constituyen los agentes sociales que participan en el movimiento, sus expectativas, el "por qué mataban y por qué morían". La integración socialmente conflictiva en el movimiento, su escalada al poder y los factores que conducen al enfrentamiento armado son los aspectos más relevantes de su trabajo que, sin embargo, obliga a repensar su caracterización de los "señores de la guerra en lucha contra los caballeros", con un posicionamiento ideológico definido como radicalizado y no radical, antiseñorial y no subversivo (Terol I Reig, 2000: 51 y 70). Si bien este autor acierta a centrar su atención en la violencia política antes y durante la revuelta, no compartimos su elección por el pánico como variable explicativa de los sucesos. ${ }^{14}$ Sin embargo, con Terol sostenemos que es esta violencia agermanada, aquella en la que hace hincapié la "versión oficial" destinada a la criminalización del movimiento, el coto de investigación más fértil para la interpretación del conflicto como lo postulamos a continuación, un terreno aún no lo suficientemente explorado.

\section{Un balance historiográfico: una ausencia en el relato histórico}

De las diversas etapas del recorrido historiográfico y de la multiplicidad de aportes relevados, podemos afirmar en principio que, dentro de una historiografía española caracterizada por su impronta localista y regionalista, la revuelta agermanada como objeto de investigación ha merecido una atención constante por parte de los especialistas locales. Se advierte la particular importancia del conflicto en el análisis histórico con una producción en permanente actualización que ha buscado y logrado múltiples abordajes a esta problemática. Cabe destacar esta valoración positiva de conjunto de estas contribuciones especializadas que han permitido un conocimiento en profundidad del fenómeno histórico y de sus diversos aspectos puntuales, tales como las condiciones que explican su emergencia, su composición social, su praxis, los sustratos ideológicos y contornos culturales de la rebeldía, el entramado institucional en el que se inserta, sus consecuencias, etc. Pero si bien algunos aspectos del conflicto fueron una y otra vez relevados y los caracteres centrales del episodio parecen haberse establecido hace décadas, no encontramos trabajo alguno dedicado específicamente al momento pleno de politización y radicalización ideológica que se despliega al término de la revuelta y cuya fase culminante se extiende entre el verano de 1521 hasta la derrota militar de 1522. Más en general, nos referimos al proceso que construye la segunda y última fase en la trayectoria rebelde, cuando se profundizan las posturas antagónicas generadas por el conflicto, dando paso al despliegue de acciones armadas, previas a la derrota, al castigo punitivo y al reestablecimiento del sistema de poder y dominación. 
Sin esta consideración global, la radicalización semeja en el relevamiento historiográfico a un fenómeno natural y dado, que sólo mereció ser abordado en sus aspectos puntuales tales como la emergencia del liderazgo encubertista o los bautismos forzados de moriscos y, en algunos casos se advierten insuficiencias explicativas. Es que esos aspectos particulares, creemos, solo encuentran cabal explicación a partir de un abordaje de conjunto de esta fase y problemática general. La prácticamente ausencia en el relato histórico obedece en primer lugar a la oscuridad de este objeto de estudio, que supone acceder también a lo ausente del repertorio documental. No existen testimonios escritos por la corriente radical plebeya que protagonizó esta fase, que murió en el campo de batalla y que fuera sentenciada postmortem. La reconstrucción de sus acciones, motivaciones y objetivos sólo puede ser concretada a través del relato de terceros que buscaban despegarse de su accionar o justificar su castigo. Además el historiador encuentra una seria limitación para conceptuar el proceso en una escala global, dado que es la Valencia rural y la Mallorca rural las que predominan en esta fase de la lucha. Las fuentes claramente constriñen la interpretación. Con todo, la moderna historiografía especializada ha acertado en establecer una visión dicotómica del bando rebelde en moderados y radicales, pero en muchos casos descalifica a estos últimos siguiendo, en la ausencia documental, los tópicos de las fuentes y destacando el progresismo documentado de la primera fase del movimiento, que supuestamente fuera arruinado por la violencia y la guerra del momento postrero del conflicto. En la mayoría de los análisis especializados, el despliegue de la guerra clausura la exégesis de la política agermanada; la interpretación se detiene precisamente donde debería comenzar y se adopta en cambio un enfoque descriptivo de batallas y acciones. El enfoque político-institucional se suma al tradicional relato de acontecimientos militares. Salvo la condena como pretensión absurda del fanatismo religioso, esta violencia final rebelde descripta a través de la lente de los cronistas oficiales y sin mayores esfuerzos interpretativos obliga a que los que fueran "desmandados" en el siglo XVI lo sigan siendo hasta el presente. Se hace necesario comprender su lógica de comportamiento en el contexto situacional. Pero en más de una ocasión, hallamos en lugar de este análisis la apelación al recurso de psicologizar las causas de la violencia agermanada considerada "irracional", sin indagar las cualidades e importancia que la misma ha tenido en el proceso de lucha social y política.

Acerca de esta importancia, postulamos que esta fase particular que lleva la impronta de la violencia resulta clave en la definición de la singularidad y carácter de la lucha agermanada. Una radicalización que no es un fenómeno dado sino que fue construida a partir de una serie de procesos que tienen su origen en la dinámica política creada por la sociedad insurreccional y entre ellos cabe destacar la polarización social y política, la extensión inusitada de la rebeldía y la asunción programática de la lucha antiseñorial, la ofensiva contrarrevolucionaria y criminalización de la revuelta y el relevo en su conducción con nuevos mandos provenientes de la corriente radical plebeya. Es recién entonces y en esta fase que la revuelta despliega un programa, plasmado en sus acciones, de supresión del régimen señorial y de todo mecanismo de exacción tributaria, de aniquilamiento de los órdenes de privilegio, de liquidación de las bases del poder económico en términos de propiedad y recursos e igualación de las condiciones sociales y finalmente de destitución real y creación de una monarquía de los no privilegiados; la Germanía adquiría carácter universal por medio de la articulación de luchas regionales en una estrategia de unificación peninsular. Por tanto, al ponderar la importancia del corto tiempo de radicalización frente al conjunto del proceso, afirmamos que la misma radica en haber construido un campo antagónico de oposición política que redefinió no sólo el carácter de la lucha sino también la identidad individual y colectiva de los alzados (Parma, 2017). 
15. Nos referimos al episodio rebelde que se despliega en 1693 conocido como la "Segunda Germanía",

con varias diferencias en términos

de acciones, protagonistas y resultados pero donde es categórico que los alzados se autonominan como ejército de la Germandat en función de la conservación en la memoria popular del primer conflicto, pese a su derrota militar. Sobre este conflicto del siglo XVII: Pérez Aparicio (1998: 247-280).

16. El concepto de violencia o dominación sistémica en: Žižek (2010).
Los clivajes políticos por guiar la insurrección y decidir las líneas a seguir, creados por la radicalización explican que, pese a la derrota, una revuelta se transforme en marco de referencia cultural para la acción colectiva venidera. Es durante esta fase que la praxis agermanada logró la gestación de nuevos niveles de materialidad a través de la práctica de los bautismos forzados de moriscos, validados posteriormente por la Corona, que a largo plazo fueron determinantes en el quiebre del sistema. Su irrentabilidad conlleva al cambio estructural establecido por el decreto de expulsión de 1609 y a la emergencia de una materialidad modificada que fue condición de posibilidad de revueltas posteriores. ${ }^{15}$ La Germanía en armas se transformó así en repertorio cultural de la lucha social del siglo XVII pero también en mito nacional y bandera heroica durante las luchas románticas del XIX como vimos en los comienzos de este artículo. Estas repercusiones materiales y culturales sólo pueden encontrar explicación partiendo de la centralidad de la fase final en la evaluación del conjunto del proceso histórico: creemos que sólo la interrupción de la dominación sistémica que esta fase provocó es lo que permite explicar la conversión de la revuelta en un horizonte de referencia para las luchas posteriores. ${ }^{16}$ Por tanto, una historiografía abundante y de calidad pero que en líneas generales no intente profundizar el análisis sobre esta fase y exalte sólo la cara bella de la moderación, mientras se mantiene casi en sombras la violencia bárbara de la revuelta no permite reconstruir, en definitiva, la significación revolucionaria alcanzada por el conflicto. 


\section{Q Bibliografía}

" Agustí Soler, M. D. (2002). Las Germanías en la Gobernación de la Plana, Diputación, Castelón.

"Aurell, M. (1997). “Messianisme royal de la Couronne d'Aragón (14e-15e siècles)”, Annales, Histoire Sciences Sociales, $\mathrm{N}^{\circ}{ }_{1}$, Paris, pp. 119-155.

»Ballester Julbe, C. (2006). La Germanía de Játiva, Maxtor, Valladolid.

» Belenguer Cebrià, E. (1979). "Coyuntura económica: el contradictorio marco económico valenciano precipitó el levantamiento agermanado”, Historia 16, Nㅜ 33, Valencia, pp. 5664.

"Benítez Sánchez Blanco, R. (1996). "El verano del miedo: conflictividad social en la Valencia agermanada y el bautismo de mudejares, 1521", Estudis: Revista de historia moderna, $\mathrm{N}^{\circ} 22$, Valencia, pp. 27-52.

" BENÍTEZ SÁNCHEZ BLANCO, R. (2000). “¿Cristianos o bautizados? La trayectoria inicial de los moriscos valencianos, 1521-1525”, Estudis: Revista de historia moderna, № 26, València, pp. 11-36.

"Benítez Sánchez Blanco, R. (2001). Heroicas decisiones: la monarquía católica y los moriscos valencianos, Institució Alfons el Magnánim, Valencia.

" Boix, V. (1845). Historia de la ciudad y reino de Valencia, Monfort, Valencia, Tomo I, p. 386.

"Boix, V. (1852). El Encubierto de Valencia. Leyenda histórica del siglo XVI, José Rius, Valencia.

"Carrasco Rodríguez, A. (1999). "Una aportación al estudio de las Germanías valencianas: el saco de Orihuela de 1521", Revista de Historia Moderna. Anales de la Universidad de Alicante, $\mathrm{N}^{\circ} 17$, Alicante, pp. 219-234.

" Castillo Del Carpio, J. M. (1996). "Diputación y Germanía: Nueva historia de una aportación financiera", Hispania, LVI / 2, № 193, Madrid, pp. 497-515.

"Dánvila Y Collado, M. (1884). Las Germanías de Valencia, Real Academia de la Historia, Madrid.

"Durán, E. (1975). “La guerra de les Germanies i la seva interpretació”, Randa, Barcelona, № 1 , pp. $25-62$.

"Durán, E. (1982).“Aspectes ideològics de les Germanies”, Pedralbes: Revista d'historia moderna, № 2, Barcelona, pp. 53-68.

"Durán, E. (1982). Les Germanies als Països Catalans, Curial, Barcelona.

"Durán, E. (ed.) (1984). Les cròniques valencianes sobre les Germanies de Guillem Ramon Català i de Miquel Garcia, segle XVI, Eliseu Climent/3i4, Valencia.

»Durán, E. (1995). “Aspectes milenaristes en les germanies valencianes”, El contemporani: revista d'història, № 5, Catarroja, pp. 21-29.

"Durán, E. y Requesens, J. (1997). Profecia i poder al Renaixement. Texts profetics catalans favorables a Ferran el Catòlic, Edicions 3i4, Valencia.

"Escandell Bonet, B. (1988). "Sebastián García Martínez y la escuela modernista valenciana”, en: M. Ardit y V.Olmos (eds.) Homenatge al Dr. Sebastià García Martínez, Generalitat Valenciana, València, I, pp. 23-45.

》Febrer Romaguera, M. V. (1996). “Provisión de cátedras y lectorados en la Universitat de 
València durante la época de las Germanías", en: E. J. y M. V. Febrer (eds.) Vida, instituciones y universidad en la historia de Valencia, Universitat de València, València, pp. 25-52.

"Febrer Romaguera, M. V. (1998). “La Universidad de Valencia en la época de las Germanías, 1519-1525", en: V. Olmos (ed.) Doctores y escolares. II Congreso Internacional de Historia de las Universidades Hispánicas, Universitat de València, València, Tomo I, pp. 125-140.

"Felipo Orts, A. (1996). "Corona y oligarquía en la ciudad de Valencia durante el reinado de Carlos V”, Estudis: Revista de historia moderna, Nㅜ 22, València, pp. 59-93.

"Felipo Orts, A. (2001). "El Síndico de la ciudad de Valencia. De las Germanías a la insaculación”, Revista de Historia Moderna, Anales de la Universidad de Alicante, № ${ }^{\circ}$, Alicante, pp. 51-78.

" Felipo Orts, A. (2004). Autoritarismo monárquico y reacción municipal: la oligarquía urbana de Valencia desde Fernando el Católico a las Germanías, Universitat de València, València.

»Fernández Herrero, M. (1870). Historia de la Germanía de Valencia y breve reseña del levantamiento republicano de 1869, Álvarez, Madrid.

» Furió, A. (1993). "Crédito y endeudamiento: el censal en la sociedad rural valenciana, ss. XIV-XV”, E. Sarasa Sánchez y E. Serrano Martín (eds.) Señorío y feudalismo en la Península Ibérica siglos XII-XIX, Instituto Fernando el Católico, Zaragoza, I, pp. 501-534.

»Furió, A. (1841). Memoria histórica del levantamiento de los Comuneros mallorquines en 1520, Pedro José Gelabert, Palma.

» Fuster, J. (1972). Rebeldes y Heterodoxos, Ariel, Barcelona.

» Fuster, J. (1992). Nosaltres els valencians, Edicions 62, Barcelona.

" García Cárcel, R. (1975). “Notas sobre la represión de las Germanías”, Cuadernos de Historia (Anexo de la revista Hispania), № 5, CSIC, Madrid, pp. 241-267.

» García Cárcel, R. (1981). Las Germanías de Valencia, Península, Barcelona.

" García Cárcel, R. (2002). "Comunidades y germanías: algunas reflexiones”, en: F. Martínez Gil (ed.) En torno a las comunidades de Castilla, Universidad de Castilla-La Mancha, Cuenca, pp. 209-230.

" García Cárcel, R. (2013). “Las Germanías de Valencia”, La nobleza en tres momentos de la Historia del Reino de Valencia: ciclo de conferencias, Fundación cultural, Valencia, pp. 15-41.

" Gimeno Roselló, M. J. (1995). Las germanías en Paterna: el tejido artesanal alfarero (15201521), Ayuntamiento, Paterna.

"Hauf I Valls, A. G. (1990). D'Eiximenis a Sor Isabel de Villena. Aportació a l'estudi de la nostra cultura medieval, Abadía de Montserrat-Institut de Filología Valenciana, Barcelona.

» Juan Vidal, J. (1975). “La problemática de los censales. Su incidencia en las Germanías (1521-1523)”, Mayurqa, № 13, Palma de Mallorca, pp. 101-158.

" Milhou, A. (1982). "La chauve-souris, le nouveau David et le Roi Cache (trois images de l'empereur des derniers temps dans le monde ibérique: XIIle-XVIle s.)", Mélanges de la Casa de Velázquez, XVIII, Centre Nacional de la Recherche scientifique, Paris, pp. 61-78.

»Nalle, S. T. (2002). "Revisiting El Encubierto. Navigating between visions of heaven and hell on earth", en: K. Edwards (ed.) Werewolves, witches and wandering spirits. Traditional belief $\varepsilon$ folklore in Early Modern Europe, Truman State University Press, Kirksville, pp. 77-92.

" Narbona Vizcaíno, R. (2006). "La milicia ciudadana en la Valencia medieval”, Clio \& Crimen, $\mathrm{N}^{\circ}$ 3, Durango, pp. 305-332. 
»PARDO MOLERO, J. F. (1997-1998). “Per salvar la sua ley. Historia del levantamiento, juicio y castigo de la villa de Benaguacil contra Carlos V, 1525-1526”, Sharq Al-Andalus, № 14-15, Teruel, pp. 113-154.

»PARDO MOLERO, J. F. (200o). “Frontera i croada. Defensa del regne, defensa de la fe”, AA. VV. Carolus Rex Valentiae: los valencianos y el imperio, Biblioteca Valenciana, Valencia, pp. 114-131.

» PARDO MOLERO, J. F. (2001). La defensa del Imperio. Carlos V, Valencia y el Mediterráneo, Sociedad Estatal, Madrid.

» PARDO MOLERO, J. F. (2004). “El Segundo Plano del Imperio (1522-1526)”, en; M. Rizzo, J. Ruiz Ibañez y G. Sabatini (eds) Le forze del Principe. Recursos, instrumentos y límites en la práctica del poder soberano en los territorios de la monarquía hispánica, Universidad de Murcia, Murcia, II, pp. 583-606.

»PARDO MOLERO, J. F. y RUIZ IBAÑEZ, J. J. (2007). “Una monarquía, dos reinos y un mar. La defensa de los reinos de Valencia y Murcia en los siglos XVI y XVII”, en: R. Cancilia (ed.) Mediterraneo in Armi (secc. XV-XVIII), Quaderni di Mediterranea, Palermo, II, pp. 429-466.

» PARMA, M. V. (1999). Estados de la cuestión: Germanías. Facultad de Filosofía y Letras, Buenos Aires.

»PARMA, M. V. (2001-2002). “Fiesta y revuelta. La teatralidad política en Valencia a principios de la modernidad”, Cuadernos de Historia de España, $N^{\circ} 77$, Facultad de Filosofía y Letras-UBA, pp. 145-164.

» PARMA, M. V. (2002). “Las ideas bajomedievales eximinianas y la lectura agermanada de principios de la modernidad", Actas de las Primeras Jornadas de Historia de España, Fundación, Buenos Aires, Tomo V, pp. 39-68.

» PARMA, M. V. (2005). “Almas al cielo y dinero a las bolsas. Bautismos y ejecuciones en la naciente modernidad valenciana”, Cuadernos de Historia de España, LXXIX, Buenos Aires, pp. 91-113.

» PARMA, M. V. (2005). “La solidaridad campo-ciudad a principios de la modernidad: el caso agermanado", Anales de Historia Antigua, Medieval y Moderna, 37-38, Buenos Aires, pp. 187-216.

» PARMA, M. “Guerras plebeyas. Lucha política en las revueltas de la temprana modernidad: aspectos teóricos, estudio del caso agermanado y análisis comparativo”, 2017. Tesis doctoral inédita, Facultad de Filosofía y Letras (UBA)

»Pérez Aparicio, C. "Reivindicaciones antiseñoriales en el país valenciano. De la Segunda Germanía a la Guerra de Sucesión”, Estudis: Revista de historia moderna, №24, Valencia, 1998, pp. 247-28o.

»Pérez García, P. (1990). La comparsa de los malhechores. Valencia 1479-1518, Diputación, Valencia.

"Pérez García, P. (1996). “Conflicto y represión: la justicia penal ante la Germanía de Valencia (1519-1523)”, Estudis: Revista de historia moderna, № 22, València, pp. 141-198.

»Pérez García, P. (2006). “Las mujeres y las germanías de Valencia”, en: R.Córdoba de la Llave (ed.) Mujer, marginación y violencia entre la Edad Media y los tiempos modernos, Universidad de Córdoba, Córdoba, pp. 311-332.

»Pérez García, P. y Catalá Sanz, J. A. (200o). Epígonos del encubertismo. Proceso contra los agermanados de 1541, Biblioteca Valenciana, Valencia.

»Piles Ros, L. (1952). “Aspectos sociales de la Germanía de Valencia”, Estudios de Historia Social de España, II, Madrid, pp. 431-478. 
» Pinilla Pérez De Tudela, R. (1987). “Apuntes en torno a un aspecto económico de la represión de las Germanías. La composición en la comarca de la Ribera”, Saitabi, N 37 , Valencia, pp. 159-171.

»Pinilla Pérez De Tudela, R. (1994). Valencia y doña Germana. Castigo de agermanados y problemas religiosos, Consell, Valencia.

»Quadrado, J. M. (ed.) (1896). Informacions judicials sobre’ls adictes á la germanía en la ciutat é illa de Mallorca, penas de cos é d'haver á ells imposadas aprés la reducció de 1523 , Estampa de Felip Guasp, Palma de Mallorca.

" Quadrado, J. M. (1930). “Sobre la Germanía. Síntesis del movimiento revolucionario”, Boletín de la Sociedad Arqueológica Luliana, № V, Palma de Mallorca, pp. 1-82.

» Redonet, L. (1959). “Comentarios sobre las comunidades y las germanías”, Boletín de la Real Academia de la Historia, CXLV, Madrid, pp. 7-16.

» Reglà, J. (1974). Estudios sobre los moriscos, Ariel, Barcelona, pp. 21-22.

»Salvador Esteban, E. (ed.) (2000). Conflictos y represiones en el Antiguo Régimen, Universitat de València, València.

»Santamaría, A. (1971). “Sobre los orígenes de la Germanía de Mallorca”, Mayurqa, № V, Palma de Mallorca, pp. 25-40.

» Serra, J. (2004). “Voces de profetas en las Germanías de Mallorca (1521-1523)”, en: A. Alvar Esquerra, J. Contreras y J. I. Ruíz Rodríguez (eds.) Política y cultura en la época moderna (cambios dinásticos, milenarismos, mesianismos y utopías), Fundación Española de Historia Moderna, Madrid, pp. 565-578.

» Terol I Reig, V. (1999). “Vespres de Germania a Ontinyent: els avalots antifiscals de 1519”, Alba: revista d'estudis comarcals de la Vall d'Albaida, 13-14, Ontinyent, pp. 41-56.

» Terol I Reig, V. (2000). “Contra cavallers i en defensa del Reial Patrimoni. Temps de Germania”, en: AA. VV. Carolus Rex Valentiae. Els valencians i l'imperi, Biblioteca Valenciana, Valencia.

» Terol I Reig, V. (2002). “La Germanía en la gobernación foral de Xátiva”, Estudis: Revista de historia moderna, $\mathrm{N}^{\circ} 28$, Valencia, pp. 509-520.

» Terol I Reig, V. (2005). “L'ombra de la Germania: Dissidència política i contestació popular en una vila valenciana (Ontinyent, segles XVI y XVII)", Afers: fulls de recerca i pensament, XX: 52, Catarroja, pp. 653-668.

» Terol I Reig, V. (2009). “En lo temps de la Germania. Llegenda negra i realitat de la matança de moriscos del castell de Polop de la Marina (1521)", Afers: fulls de recerca i pensament, XXIV: 62/63, Catarroja, pp. 9-14.

» Torres De Castilla, A. (1866). Historia de las persecuciones políticas y religiosas ocurridas en Europa desde la Edad Media hasta nuestros días, Salvador Manero, Barcelona.

»Vallés Borràs, V. (1990). Bases ideológicas y programa reivindicativo de la Germanía, Ediciones histórico-artísticas, Valencia.

» Vallés Borràs, V. (1996). “Notarios y juristas al servicio de la Germanía”, Estudis: Revista de historia moderna, № 22, València, pp. 203-226.

»Vallés Borràs, V. (2000). La Germanía, Institució Alfons el Magnànim, Valencia.

»Vallés Borràs, V. (2000). “La Germanía (1519-1522): un movimiento social en la Valencia del Renacimiento”, en: E. Salvador Esteben (ed.) Conflictos y represiones en el Antiguo Régimen, Universitat de València, València, pp. 11-20.

» Vallés Borràs, V. J. (2008). “La Germanía y la Corona de Aragón”, en R Franch Benavent 
y R. B. Sánchez Blanco (ed.) Estudios de historia moderna en homenaje a la prof. Emilia Salvador Esteban, vol. 1, Universidad de Valencia, Valencia, pp. 491-504.

»Valor Moncho, P. (2000). “El Consell General y la lucha por el poder municipal: origen y desarrollo de las Germanías de Valencia, 1515-1523”, Estudis: Revista de historia moderna, № 26, València, pp. 227-242.

»Valor Moncho, P. (2001). "Los miembros del Consell General de Valencia desde la muerte de Fernando el Católico hasta las Germanías, 1515-1523”, Revista de Historia Moderna, Anales de la Universidad de Alicante, $\mathrm{N}^{\circ}{ }_{19}$, Alicante, pp. 11-38.

»Vaquer Bennasar, O. (2000). “La repressió dels agermanats”, Mayurqa, N²6, Palma de Mallorca, pp. 57-71.

»Žižek, S. (2010). Sobre la violencia. Seis reflexiones marginales. Paidós: Buenos Aires. 
